\title{
SUBJETIVIDADE, MONTAGEM E ÉTICA NO CINEMA DOCUMENTÁRIO: PISTAS METODOLÓGICAS ENTRE EDUARDO COUTINHO E WALTER BENJAMIN
}

\author{
Pedro Felipe Moura de ARAÚJO ${ }^{1}$ \\ Marcelo Santana FERREIRA ${ }^{2}$
}

\section{Resumo}

Instituição de um regime cinematográfico, o documentário se estabeleceu sob uma forte conotação representacional, e tornou-se um método para fornecer, a partir de imagens, um sentido de factualidade à investigação da realidade. A narrativa documentária dominante ancora-se em tons conclusivos sobre o real, produz endereçamentos pré-estabelecidos entre histórias e imagens, constrange os acasos. Para Walter Benjamin, os vencedores narram a história de uma perspectiva continuísta e teleológica. Os derrotados emergem nestas narrativas como carentes e destituídos de coragem ou de ousadia. A imagética da derrota se subsidia na naturalização da miséria, no embotamento de qualquer sensibilidade coletiva - e, portanto, política - que se possa forjar sobre a miséria. O modo como se retrata o outro e o mundo são índices das relações de poder em jogo, implicam posições e apostas éticas. Nestas linhas que aqui se tecem entre a escrita da história e a experiência fílmica do documentário, desejou-se produzir um deslocamento na tradição histórica dos vencedores pela via de um outra imagética dos derrotados, apontada no documentário "Boca de Lixo", do cineasta Eduardo Coutinho. O método de construção das imagens em "Boca de Lixo" se aproximaria das pistas benjaminianas para a atividade do historiador materialista, para o qual o passado deixa de ser um fato objetivo e transforma-se em um fato de memória, uma "atualidade intensiva". Em "Boca de Lixo" Coutinho aciona uma interrupção das representações e clichês que temos da miséria e do lixo através de imagens de um "presente que destrói o contínuo da história" (BENJAMIN, 2009).

Palavras-chave: documentário, imagem, história, ética, subjetividade.

\begin{abstract}
Institution of a cinematographic regime, the documentary was established under a strong representational connotation, and became a method to provide, from images, a sense of factuality to the investigation of reality. The dominant documentary narrative anchors itself in conclusive tones on the real, produces pre-established addresses between stories and images, constrains the accidents. For Walter Benjamin, the winners narrate the story from a continuist and teleological perspective. The defeated emerge in these narratives as needy and devoid of courage or daring. The imagery of defeat is subsidized in the naturalization of misery, in the dulling of any collective sensibility - and therefore political - that can be forged about misery. The way one portraits the other and the world in these narratives are indices of the power relations at stake, imply positions and ethical bets. In these lines that are woven between the writing of history and the film experience of the documentary, we intended to produce a displacement in the historical tradition of the winners by way of another image of the defeated, pointed out in the documentary "Boca de Lixo", by the filmmaker Eduardo Coutinho. The method of constructing the images in "Garbage Mouth" would approach the Benjaminian lanes for the activity of the materialist historian, for whom the past ceases to be an objective fact and becomes a fact of memory, an "intensive actuality". In "Mouth of Garbage" Coutinho triggers an interruption of the representations and clichés

${ }^{1}$ Pedro Felipe Moura de Araújo é graduado em psicologia pela Universidade Federal da Paraíba, mestre em Estudos da Subjetividade pela Universidade Federal Fluminense, onde atualmente realiza pesquisa de doutorado. E-mail: peehfe@gmail.com

2 Marcelo Santana Ferreira. Mestre e doutor em Psicologia pela PUC/RJ. Professor Associado de psicologia Social no Instituto de Psicologia da UFF/Niterói. Professor do programa de pós-graduação em Psicologia: Estudos da Subjetividade, da UFF. E-mail: mars.ferreira@ yahoo.com.br
\end{abstract}




\section{Subjetividade, montagem e ética no cinema documentário: pistas metodológicas entre Eduardo Coutinho e Walter Benjamim.}

Pedro Felipe Moura de ARAÚJO; Marcelo Santana FERREIRA

we have of misery and garbage through images of a "gift that destroys the continuum of history" (BENJAMIN, 2009).

Keywords: documentary, image, history, ethics, subjectivity.

\section{Resumen}

La institución de un régimen cinematográfico, el documental se estableció bajo una fuerte connotación representacional, y se convirtió en un método para proporcionar, a partir de imágenes, un sentido de factualidad a la investigación de la realidad. La narrativa documental dominante se ancla en tonos concluyentes sobre lo real, produce direccionamientos pre-establecidos entre historias e imágenes, constreñe los acasos. Para Walter Benjamin, los vencedores narran la historia desde una perspectiva continuista y teleológica. Los derrotados emergen en estas narrativas como carentes y destituidos de coraje o de osadía. La imagética de la derrota se subsidia en la naturalización de la miseria, en el embotamiento de cualquier sensibilidad colectiva - y, por lo tanto, política - que se pueda forjar sobre la miseria. El modo como se retrata el otro y el mundo son índices de las relaciones de poder en juego, implican posiciones y apuestas éticas. En estas líneas que aquí se tejen entre la escritura de la historia y la experiencia fílmica del documental, se deseó producir un desplazamiento en la tradición histórica de los vencedores por la vía de otra imagética de los derrotados, apuntada en el documental "Boca de lixo", del cineasta Eduardo Coutinho. El método de construcción de las imágenes en "Boca de lixo" se aproximaría a las pistas benjaminianas para la actividad del historiador materialista, para lo cual el pasado deja de ser un hecho objetivo y se transforma en un hecho de memoria, una "actualidad intensiva" . En "Boca de Lixo" Coutinho acciona una interrupción de las representaciones y clichés que tenemos de la miseria y de la basura a través de imágenes de un "presente que destruye el continuo de la historia" (BENJAMIN, 2009).

Palabras - clave: documental, imagen, historia, ética, subjetividad.

\section{ALGUMAS NOTAS, CONVIVER COM IMAGENS}

O filósofo Gilles Deleuze via no cinema uma pedagogia da imagem que jamais houve, uma pedagogia como necessidade intensa do outro. Se pensarmos a criação/invenção como um nascer de novo, esta precisaria de outrem, pela fragilidade das novas questões a emergir. Para o crítico e cineasta Jean-Louis Comolli o cinema seria uma massa plástica que nos atinge para além da história. Deleuze diria que o cinema pode ser uma forma de, assim como sua filosofia, inverter o platonismo, isto é, “'fazer subir os simulacros', subverter o mundo da representação" (RODRIGUEZ, 2015, p. 92) A imagens de cinema podem nos aparecer em diferentes modulações: seja por excesso, como nos cortes e cores e citações de um Godard; seja nos vazios, como os desertos narrativos dos filmes de Antonioni. As imagens de cinema nos demandam, nos fazem desejar, solicitam dos dizíveis aos invisíveis que nos constituem, e as conversas alongam os filmes no mundo. Imagem que afeta e produz o real, e também o interroga: imagens enquanto não reconciliação com o mundo. A montagem cinematográfica, seu método de fazimento, é um primeiro gesto que perturbaria as conexões entre a imagem e 
o real. Por quais caminhos um montante de imagens pode apresentar uma experiência? Cinemontagem ou a montagem como um fazer contar, tecer um mundo para os olhos, em meio aos corpos. A montagem como plano sensível que parte de um olhar. Existem distâncias e paradoxos entre o filmado e o montado e, assim como nos lembra o crítico André Bazin, não seria papel do cinema esvaziar a ambiguidade do real. Para o cineasta Robert Bresson, um filme se faz nas zonas de conexão das montagens, na faísca de significação que chamusca entre uma imagem e outra, a que a antecede e a que vem. Poderia o cinema operar como uma forma que pensa, para além daquilo que parece representar ou se encerrar em sua imagem?

Como disparadores do pensar, estas breves máximas acima intentam pensar a particularidade do discurso sensível produzido por filmes, da escrita cinematográfica, na sua forma de operar com imagens e montar histórias. Mais especificamente nos debruçaremos sobre o cinema documentário, quando este é pensado e não desvinculado de sua materialidade ética: nos acordos e formas de contato com o outro, nas partilhas e visibilidades de uma experiência que são sugeridas pelas imagens. Como ponto de partida, apostamos em duas condições que atravessam o cinema documentário: (I) o paradoxo da obra e sua fabricação, ao tempo que o filme parte de uma experiência singular de encontro com o real; (II) o ato de montar uma estrutura narrativa nas/das malhas e travessias de acontecimentos vividos e filmados.

\section{COMO FILMAR REPRESENTAÇÕES EM ANDAMENTO? O DOCUMENTÁRIO E O OUTRO}

No livro Filosofia Mestiça, o sociólogo Michel Serres relata que na produção do conhecimento, primordialmente o ocidental, teríamos dois focos. Um deles seria o foco luminoso da razão, onde o personagem de Ulysses, na narrativa da Ilíada de Homero, seria a sua alegoria: aquele que vai cegar o ciclope de maneira astuta, que ardilosa e calculadamente consegue enganá-lo. O outro foco ele chama de "sol negro", onde os saberes seriam fundados não mais sob os auspícios do épico vitorioso, mas no inevitável do trágico, no ambíguo dos acontecimentos, na fragilidade e no sofrimento humano. O saber oficial seria esse conduzido pelo foco da razão, espécie de iluminação e dominação da coisa a ser conhecida; já o outro foco do conhecimento, na imagem opaca de um sol escurecido, seria atributo da cultura e 
suas múltiplas e silenciosas formulações.

O pesquisador César Guimarães (2014, informação verbal) ${ }^{3}$ pontua este brevíssimo fragmento da obra de Serres para nos convocar a ver que o cinema dcumentário hospedaria esta potência de produzir saberes tal qual iluminados por um sol turvo e incerto: de fazer cambalear as pré-concepções sobre o mundo, de inventar e mostrar um habitat para os paradoxos da história e ambivalências do real. Aparece aqui uma possibilidade para pensar as imagens em suas potências de ruptura dos caminhos únicos de uma história. A experiência cinematográfica instaura outras temporalidades nos processos de subjetivação, pode reconfigurar perguntas para os impasses do real. Imagens extraídas de um mundo que venha a produzir torções nas representações estabelecidas, fazer vibrar os cânones do já sabido e, seguindo o conselho nos enviado por Bazin, não esvaziar a ambiguidade do real. De que valeria, ao mesmo tempo, esta aposta e esta provocação?

Enquanto palavra e domínio específico do cinema, o documentário começou a se estabelecer entre os anos 1920 e 1930 na Inglaterra, trazendo as marcas de sua significação do campo das ciências humanas, para designar um conjunto de documentos com a consistência de prova a respeito de uma época. Instituição de um regime de imagens, a premissa documentária designou-se a partir de uma forte conotação representacional, um sentido histórico de veracidade factual de um tempo e espaço dados (TEIXEIRA, 2007). A representação se apoia em convenções socializadas para marcar seu lugar de existência, que se quer reconhecível e detectável. Ao se produzir o acoplamento direto entre discursos de verdade e imagens do outro, se acreditou produzir uma ideia única sobre um povo ou comunidade, sobre um lugar ou determinada classe, isto é, uma história concluída: vontade de captura e exercício do foco iluminador da razão.

Um dos problemas centrais da representação é saber em que medida ela se confunde com o que representa; a empiria de sua produção. E também saber o quanto há de arbitrário e o quanto há de motivado na mesma. Alçar a produção do saber científico a um valor transcendental é limar as possibilidades de intervenção do acaso, querer tornar fato encerrado uma imanência complexa como são os encontros humanos, por exemplo. Certa inadequação da representação (REZENDE, 2013) documentária do mundo só adquiriu o status de

\footnotetext{
${ }^{3}$ Palestra apresentada no cineclube da UFRJ Ciência em Foco, intitulada "A experiência histórica e o irreparável”.
} 
evidência à medida que diversas abordagens críticas afirmaram que o documentário é muito menos uma porção de realidade do que uma imagem construída, e que o cinema não é um instrumento fiel de apresentação do real.

\begin{abstract}
É que a representação opera sempre em uma dupla direção contraditória: em direção à coisa, pelo viés da semelhança, e em direção à sua ausência, pela miragem, o falso prestígio que ela constitui. Ela coloca, assim, o espectador frente a seu desejo - de que haja alguma coisa em vez de nada - só para lhe demonstrar que é simultaneamente que 'alguma coisa' e 'nada' são dados, na emergência escandalosa do simulacro. E sobra para o espectador se virar com as liberdades que o simulacro toma, quando este deixa de se comportar como um reflexo obediente. (BONITZER apud REZENDE, 2013, p. 52)
\end{abstract}

Problema de ordem prática na representação: existe sempre algo do sujeito/objeto que não obedece, que é do campo do irrepresentável, invisível/virtual, principalmente quando falamos da experiência polifônica das imagens. O cineasta filma no máximo representações em andamento (COMOLLI, 2008) uma disputa viva com o outro nas bordas do que se planeja, mas que não se controla por inteiro. O que é colocado à disposição do espectador, o que acende ou recoloca em movimento o seu desejo de ver são corpos filmados garantidos como verdadeiros por aqueles que têm o poder de mostrar.

Não se filma nem se vê impunemente. Como filmar o outro sem dominá-lo ou reduzi-lo? Como dar conta da força de um combate, de uma reivindicação de justiça e de dignidade, da riqueza de uma cultura, da singularidade de uma prática, sem caricaturá-las, sem traí-las com uma tradução turística ou publicitária? Como construir para nossos espectadores um percurso de liberdade e de subjetividade? (COMOLLI, 2008, p. 30)

Problema de ética no documentário: se, como nos diria Comolli, "a paixão da figura humana" é um dos motores das imagens documentárias, como dar conta de singularidades que rompem com a versão imóvel da representação? Como problematizar sua insuficiência frente o que acontece? Não se trata de negar o valor político do filme documentário que tenciona se ancorar em pressupostos sociais estabelecidos, mas o problema é como ele opera e faz uso dessa relação, o que escolhe mostrar ou esconder.

\title{
3. O REAL FABRICADO POR MONTAGENS
}

Quem faz um filme sempre retorna algo para o mundo. Um documentário é sempre retorno, entregar de volta. Ao devolver "um mundo" ao mundo, o filme documentário fabula 


\section{Subjetividade, montagem e ética no cinema documentário: pistas metodológicas entre Eduardo Coutinho e Walter Benjamim.}

Pedro Felipe Moura de ARAÚJO; Marcelo Santana FERREIRA

a partir de lugares e pessoas uma história que retorna. E no caso do cinema documentário, onde são extraídas histórias e imagens que aparecem como constituição do mundo? Como pensar as imagens do real, entre o que estas representam e os acontecimentos de uma experiência fílmica? As imagens de um filme documentário são ambíguas: em seu aspecto material, são registros de movimentos e gestos corporais, arquivos e vozes; um tempo real cortado pela luz e guardado por uma câmera; em outra camada, numa espécie de dimensão mágico/sensível, essas imagens são memórias e figurações do humano, duração e exercício do tempo; conversas e encontros filmados que tecem mundos e evidenciam as relações de poder entre os viventes, inventam formas de humanidade. Estas pontuações sustentam afinidades com duas categorias, comumente preteridas na apreensão do mundo pelas lentes do conhecimento oficial ou "verdadeiro" das coisas: o par afeto/subjetividade.

No campo da enunciação documentária, o problema do verdadeiro e do autêntico não pode se esquivar dos efeitos e construções ficcionais que incitam no real, pois as imagens são constituídas nos embates dos realizadores com pessoas/personagens, da câmera com o mundo. A câmera não seria apenas registro do que já estaria enquanto verdade no real, mas antes de tudo o forja, produz um recorte espaço-temporal do real com histórias, arquivos ou pessoas filmadas. Função ainda por vezes requisitada às imagens do real, em sua forte conotação representativa e comprobatória de mundo, o verdadeiro no cinema documentário pode ser mais arbitrário do que factual.

O documentarista Joris Ivens, um dos pioneiros do campo, disse que um documentário é a "apresentação emocional dos fatos" (2015, p. 44), fazendo sobressaltar o caráter subjetivo que reside na tensão entre a vivência dos acontecimentos e a operação de sua montagem. Frederick Wiseman, figura central da escola do documentário observacional, provoca quando afirma que "qualquer documentário, meu ou de outros, de qualquer estilo, é arbitrário, tendencioso, preconceituoso, restrito e subjetivo" (2015, p. 186). Já para o cineasta Eduardo Coutinho, talvez o mais importante realizador de documentários no Brasil, não existiria verdade no cinema documentário, mas apenas uma verdade da filmagem que busca "revelar em que situação, em que momento ela [verdade] se dá e todo o aleatório que pode acontecer nela" (1997, p. 168). Como sugerido no montante de afirmações destiladas no primeiro fragmento acima, a montagem é a operação de um ponto de vista. No caso do documentário, é um gesto que pode perturbar uma ideia complacente de realidade ao 


\section{Subjetividade, montagem e ética no cinema documentário: pistas metodológicas entre Eduardo Coutinho e Walter Benjamim.}

Pedro Felipe Moura de ARAÚJO; Marcelo Santana FERREIRA

explicitar as contradições dos encontros no mundo, as nuances de uma experiência singular de amostração do real.

Para o realizador e crítico de cinema Jean-Louis Comolli (2015) o ato de mostrar no cinema "nada tem de passividade, de inércia, de neutralidade", pois esta ação - mesmo ao induzir um caráter de transparência - "permanece opaca", tornando-se índice de "não indiferença" (p. 166) daquele e daquilo que mostra. Uma das peculiaridades do cinema é operar por montagens que se relacionam com os visíveis e invisíveis das imagens. No caso de um filme documentário - onde a abertura ao encontro com o real se faz pressuposto e ferramenta narrativa - a prática da montagem impele escolhas éticas para com os encontros que forja, com as figurações que produz e os personagens que cria a partir de pessoas de carne e osso, situações que atravessam a poeira dos tempos.

As definições mais canônicas sobre o cinema documentário, em relação à uma suposta "pura objetividade" - como reflexo do mundo ou captura de uma verdade unívoca nunca foi arguida por seus realizadores, mas sim perpetrada por um senso comum jornalístico que ganha corpo com a televisão e a cibernética. As imagens do real a que somos constantemente expostos - nas redes sociais, nos roteiros e espetáculos da telerrealidade -, buscam ofuscar o caráter processual de suas imagens. A aventura contraditória na captação destas imagens, como registro factual da realidade, é comumente apaziguada por montagens que seguem roteirizações pré-estabelecidas para a experiência de uma filmagem. As formas de apresentação sensível de um filme podem ora reforçar, ora fragmentar e multiplicar, as representações que carregamos; produzir novas sínteses para o real, complexificar suas questões. A operação da montagem pode ampliar as ordenações entre signos, sujeitos e temporalidades, pode inaugurar um espaço em que nem as imagens nem as histórias tenham um sentido único, onde o documentarista pode se permitir

[...] abrir portas sem percorrer todo o caminho, andar aos pulos em velocidades variadas, não porque tenha pressa, mas porque precisa ensaiar possíveis conexões sem necessariamente desenvolvê-las, precisa associar espaços sem obrigatoriamente conhecêlos em sua totalidade, o que é muito diferente de ser superficial. (MIGLIORIN, 2014, p. 240)

Todavia, a montagem também pode se alinhar a premissas conclusivas, num empilhar de documentos e evidências que almejam mapear endereços certos para uma história. De acordo com Migliorin, importante pensar que "nem as imagens todas são equivalentes, nem a 


\section{Subjetividade, montagem e ética no cinema documentário: pistas metodológicas entre Eduardo Coutinho e Walter Benjamim.}

Pedro Felipe Moura de ARAÚJO; Marcelo Santana FERREIRA

montagem garante todo o conhecimento", pois as imagens ainda assim "resistem ao que desejamos impor a elas" (ibid, p. 241). A montagem no cinema documentário carregaria essa potencialidade ambivalente: pode guiar-se entre categorias e representações sociais e também abrir sentidos e caminhos, retoque do real através de suas próprias imagens, ambas acontecendo sem hierarquias ou divisões exatas.

Quando se trata da presença "outro pobre”, marginalizado e/ou fora-da-ordem, alguns filmes brasileiros costumam trabalhar com imagens que tendem à representá-los pela via da pauperização ou recorrer ao terror da proximidade, com estatísticas de crime e violência no universo popular. Não se reportando as contradições no encontro de mundos diferentes, o documentarista tende a apresentar um olhar guiado sob as rédeas da miserabilidade comumente para um público de classe média, que frente ao que é exposto teme, treme e se apieda com o horror (GUIMARÃES, 2010)

Poderíamos pensar uma outra política de imagens? Interessa-nos aqui menos a aparição de um "sujeito popular" bem delimitado do que a presença das formas do viver, na qual todos os modos, os atos e os processos da experiência não são nunca simplesmente fatos, mas sempre e antes de tudo, possibilidade de vida ou potências. A tarefa crítica do documentário não seria apenas lançar uma ofuscante luz a proporcionar um lugar de glória ao que está à margem - fixá-lo em alguma particularidade que o defina -, mas conceder que este aconteça no simultâneo de suas "múltiplas faces, a impropriedade de seu rosto, a comunicabilidade pura de sua fala, irredutível a uma proposição ou a um conteúdo determinado" (GUIMARÃES, 2006, p. 41).

Uma experiência radical de alteridade poderia emergir nos encontros: perceber os imprevistos desses corpos, personagens e espectadores; evidenciar nos embates com o real as suas ambivalências; aceitar a presença da câmera que inclui o mundo e o mundo que a inclui. Seguindo as palavras de Comolli (2008), seria "trazer o poder de mostrar para própria relação que funda a possibilidade de filmar” (p. 30). As relações de poder não seriam encobertas sob o véu luminoso da representação, mas subiriam à cena em sua complexidade conflituosa. Sob esse outro ponto de vista, as visibilidades que o documentário pode alcançar devem ser avaliadas, prioritariamente, em função do modo com que seus recursos expressivos são manejados para traduzir, no domínio das formas, um problema inextricavelmente políticoestético: as aparições deste inominável outro, em sua ambiguidade e impessoalidade, 


\section{Subjetividade, montagem e ética no cinema documentário: pistas metodológicas entre Eduardo Coutinho e Walter Benjamim.}

Pedro Felipe Moura de ARAÚJO; Marcelo Santana FERREIRA

fulgurando outras subjetivações sobre o status ético da imagem no contemporâneo.

\section{A ALTERIDADE POSSÍVEL DO ENCONTRO}

Imagens de um lixão em silêncio, restos amontados em meio a cavalos e urubus. Um caminhão se aproxima e despeja sua carga indigesta rente a câmera/tela, o som do ambiente surge na imagem, assim como os primeiros humanos em cena: corpos ainda sem rostos se aglutinam ao redor do caminhão, do qual escorrem dejetos e chorume em meio a gritos e avanços, uma visão ingrata. A imagem recua, um corte interrompe a confusão, há uma outra câmera que registra aqueles que estão filmando essa agregação indigesta, ela também equilibrando-se nos detritos, por detrás daqueles que estão em busca de sobras. Entra uma trilha sonora percussiva - garimpada e orquestrada a partir de sons extraídos de objetos deste mesmo lixo ao filme -, seguindo a ritmar uma montagem feita de cortes rápidos: pessoas fugindo da mira da câmera, rostos que parecem esconder-se de sua presença. De que fogem, de quem se escondem? Em meio a uma ruidosa sinfonia de latas, faces cobertas e movimentos arredios, alguém tira o véu do rosto para a câmera, esboça um sorriso, o som cessa.

No início do filme "Boca de Lixo" (1993), de Eduardo Coutinho, nos parece óbvio que estamos em um lixão - vê-se pessoas transitando e trabalhando, caminhões e bichos em atividade nesse ambiente inóspito - mas não somos apresentados a estas imagens por alguma voz em off exterior, que nos colocaria a par do que se passa naquele território, ou de aspectos sociais e geopolíticos sobre a existência dos lixões e etc. A primeira palavra que ouvimos não explica o que está se passando, é a de um jovem, que aponta e questiona para a câmera "por quê vocês vem com isso, pra ficar botando esse negócio na nossa cara?”. Importante esse troço de começar pela palavra que brota do contato com o outro, daquele que está na frente da câmera a interrogar nosso olhar. De pronto, ouvimos a resposta de uma voz que, mesmo ainda não aparecendo, se faz presente naquele embate provisório, "pra mostrar como é a vida de vocês", dito assim, sem arrodeio ou inibição. Esse primeiro fragmento de conversa torna-se seminal em relação ao tom das imagens que seguem: o encontro com o outro não é apaziguado, nos expõe a um confronto. 


\section{Subjetividade, montagem e ética no cinema documentário: pistas metodológicas entre Eduardo Coutinho e Walter Benjamim.}

Pedro Felipe Moura de ARAÚJO; Marcelo Santana FERREIRA

Manter na montagem do filme estas resistências iniciais, como que faíscas de um primeiro contato, situa uma postura ética sobre a exposição daqueles que se desconhece, dos modos da veiculação de sua imagem. O questionamento do jovem em meio ao lixo como um alerta, sobre o poder da câmera em conectar-se ao imaginário midiático - principalmente nossas memórias da TV, com a reprodução de seus clichês e lugares comuns -, que tende a reduzir o espaço subjetivo para/com o outro em nome de suas narrativas teleguiadas pelo espetáculo. Em meio a essa complexa aproximação, como se fazer confiar que outra imagem é possível? E mais especificamente no caso de "Boca de Lixo", como conversar com quem não quer dizer nada?

Ali mesmo, nos dias em que a equipe permanece a tentar um contato, cria-se um método com o recurso da própria imagem do outro: vemos fotos xerocadas de filmagens anteriores realizadas no próprio lixão, que mostram rostos em preto e branco de homens e mulheres que lá estavam; cópias precárias que são partilhadas junto aos catadores na aposta do reconhecer de seus próximos. Este gesto metodológico daquele que filma aciona a contingência que permeará estes encontros, e indica que o que está sendo proposto "não é mais uma desapropriação da imagem alheia, segundo a lógica mediática, mas a criação de uma imagem compartilhada entre quem filma e quem é filmado, com riscos e possibilidades de equívocos." (LINS, 2004, p. 88). Esse deparar-se com o próprio rosto e os dos outros que ali convivem - as fotos que vão passando de mão em mão enquanto as figuras ali são reconhecidas entre nomes e risos - começa a tecer para nós uma ideia de comunidade espontânea ${ }^{4}$ entre estas pessoas anônimas no filme, mote esse que sem pressa vai rachando uma possível "representação social" preconcebida dos que ali circulam. No olhar das fotografias, os nomes vão sendo ditados em voz alta pelos que se reconhecem, enquanto vemos diversas imagens de rostos em close; mesmo sem garantia que os nomes e os rostos coincidam, quase como que um realce para a força da voz e a imagem de um rosto anônimo.

$\mathrm{Na}$ segunda metade do filme, uma sequência interessante para fazer pensar sobre nossa relação com os dispositivos: ao fenecer de mais um dia pelo lixão, a canção Sonho por

\footnotetext{
4 "As pessoas envergonhadas da própria imagem o documentarista oferece fotografias impressas em papel, imagens retiradas do próprio vídeo que está sendo feito. Quando uns identificam os outros pelos nomes, é a ideia de comunidade que se faz presente, em toda sua espontaneidade." (MATTOS, C. A. Eduardo Coutinho: o homem que caiu na real. Santa Maria da Feira, Portugal: Festival de Cinema Luso-Brasileiro de Santa Maria da Feira, 2003, p. 55).
} 


\section{Subjetividade, montagem e ética no cinema documentário: pistas metodológicas entre Eduardo Coutinho e Walter Benjamim.}

Pedro Felipe Moura de ARAÚJO; Marcelo Santana FERREIRA

sonho, interpretada pelo cantor José Augusto, toca no rádio e alça o lugar de trilha sonora no passar das imagens. Como uma espécie de restituição da imagem alheia, o filme segue a inventar suas formas de contato e partilha: vemos a exibição de um primeiro corte do filme para os próprios trabalhadores do lixão, com uma pequena televisão em cima de uma Kombi, aos olhares atentos no entardecer do dia, momento em que os serviços já cessaram. Uma câmera situada dentro da Kombi mira nos olhos admirados de se verem na televisão, reações fugazes captadas entre a graça e o espanto.

\section{PISTAS METODOLÓGICAS}

Filmado no lixão de São Gonçalo, em Niterói (RJ), o projeto de “Boca de Lixo” nasce em janeiro de 92, de uma visita de dois dias ao lixão durante a produção de um vídeo institucional para o Centro de Criação de Imagem popular (CECIP), nas proximidades da região, o qual Coutinho dirigia. A ideia era filmar o cotidiano na vida dos catadores de lixo daquele lugar. Durante o primeiro semestre do corrente ano foram mais duas visitas, uma em abril que durou oito dias e mais uma em junho, quando Coutinho organizou e registrou a exibição de uma primeira edição para os catadores. As visitas e o tempo transcorrido na sua realização, nos sugerem uma implicação e uma busca do outro na sua confiança, num certo "fiar junto". Nessa empreitada errante pelo cotidiano do lixão Coutinho esbarra num elemento forte do imaginário do país: o clichê da pobreza. Como filmar ali, sem desqualificar o quê e quem vive, nem horrificar a imagem de um outro e reduzi-lo? Como não tecer mais uma narrativa de impotência frente ao terrível absoluto da miséria, essa imagem imóvel do país? Sem nenhuma tese prévia, Coutinho saiu em busca das pessoas, colocou a câmera no risco destes encontros, buscou rostos e vozes em meio ao lixo, fez perguntas, se colocou no jogo.

O que produz Eduardo Coutinho a partir do processo metodológico de aproximação e montagem em "Boca do Lixo" é exercitar uma espécie de grau zero do documentário 5 para triscar em outras configurações do contato, abrir o olho da lente para a dimensão temporal

\footnotetext{
5 "Boca de Lixo parte do grau zero do documentário para estabelecer experiências únicas através da insistência, da simplicidade e de sutis estratégias de aproximação. Este, cada vez mais, vai passando a ser o seu método.” (MATTOS, Ibid).
} 


\section{Subjetividade, montagem e ética no cinema documentário: pistas metodológicas entre Eduardo Coutinho e Walter Benjamim.}

Pedro Felipe Moura de ARAÚJO; Marcelo Santana FERREIRA

das coisas e dos rostos, dispor o ouvido da câmera para outras conversas. Esses princípios não se localizam apenas num plano ideal a ser atingido, mas são tensionados na própria forma e duração das imagens, de garantir que a montagem do filme busque esta dignidade intentada nos encontros ${ }^{6}$. O desafio que leva a cabo, como filme e pesquisa que se mostram indissociáveis, é a invenção de um espaço imagético pelas veredas do bruto, que enfatize as ambivalências de uma alteridade possível.

Não há espaço para identificações simplórias nem a produção de um abrigo tranquilizador para os que do lixo vivem, num suposto humanismo travestido de culpa. $\mathrm{O}$ filme desafina a voz de confirmação de um sofrimento esperado, ao deslocar-se para o chão da palavra e do momento compartilhado, quem sabe capazes de emitir algumas centelhas particulares de humanidade não disciplinada. O olhar sobre a miséria não deixa de ter o seu peso, mas não almeja complacência enquanto postura moral nem a veia transformadora enquanto ascese macropolítica.

Coutinho faz um filme na justeza ética daquele que recorda por onde passou para fazer lembranças de outro lugar, como nos sugere Benjamin, para quem o trabalho da recordação "deve ser menos um relatório, e mais o da indicação exata do lugar onde o investigador se apoderou dessas recordações" (BENJAMIN, 2013b, p. 101). No último plano do filme - um menino vestido de uma camisa suja da franquia "Casa\&Video", com uma sacola de plástico nas costas a juntar pedaços que lhe servem -, surge quase uma proposta de acesso ao material destes encontros: nas ruínas do espetáculo, vasculhar os fragmentos a serem reunidos para inscrever uma singularidade onde o filme acontece, em meio as sobras, nas novas possibilidades de uso ao que foi descartado e esquecido. Como uma forma de pensar a realidade, pois é tributária do que as imagens do real fornecem enquanto dizível e visível, a operação da montagem no cinema documentário poderia se apresentar como essa inspiração metodológica, para talvez uma outra escrita dos fatos: na medida que evidencia a produção de aberturas insabidas no real, produz uma política sensível para as inteligibilidades do mundo. Devolve um pedaço do mundo para o próprio mundo.

\footnotetext{
6 "Não me interessa o plano curto. Eu quero a dimensão temporal das coisas. (...) As pessoas têm um tempo, têm uma memória, tem um passado, mas para isso vir à tona tem uma temporalidade, que precisa estar nos planos, na edição. Essa dimensão do tempo está no conteúdo e na forma, na memória e no plano" (Eduardo Coutinho, em entrevista concedida à Valéria Macedo em 1998, in: BRAGANÇA, F. (org.) Encontros | Eduardo Coutinho, 2008, p. 70)
} 


\section{UM ÊTHOS POR OUTRA IMAGÉTICA DOS DERROTADOS}

A aposta de Eduardo Coutinho, preservando-se a sua estética e a integridade de sua ética documental, pode dialogar, metodologicamente, com esforços de compreensão dos derrotados da história de modo não maniqueísta. Partindo do próprio sentido de derrota, a história do capitalismo não pode ser levada a cabo sem que se considere a peleja intrínseca que a constitui, em curso desde o modo como a produção e a reprodução da vida social está estruturada. Os vencedores narram a história de uma perspectiva continuísta e teleológica. Os derrotados da história dominante emergem nas narrativas oficiais como carentes, privados, destituídos de coragem ou de ousadia. A imagética da derrota se subsidia na naturalização da miséria, no embotamento de qualquer sensibilidade coletiva - e, portanto, política - que se possa forjar sobre a miséria. O documentário de Coutinho, uma vez assentado na irrepetibilidade das negociações e interações entre equipe de filmagem e filmados, também pode ser lido como o estabelecimento de um renovado êthos que não se paralisa diante dos fragmentos de vida e de resistência em curso na existência de quem vive do lixo. Partindo da resistência de alguns dos indivíduos à presença da câmera empunhada pela equipe de Coutinho, o documentário pode ser apropriado, na atual analítica, como uma ferramenta de problematização da imagem e da representação.

A resistência pode ser entendida tanto como o movimento que um corpo faz em relação a uma ação exercida sobre ele, quanto como o movimento que se inaugura na suspensão do significado dominante sobre um dado aspecto da realidade. Um movimento e uma emergência de sentido. Resistir à câmera e, ao mesmo tempo, indicar a resistência organizada como um modo de existência que não se reduz ao uso daquilo que sobrou como lixo. Há falas no documentário de Eduardo Coutinho que enumeram a contradição da condição em que os indivíduos se encontram: ali no lixo, encontram alimentos bons, forjam algumas parcerias mas gostariam de trabalhar com outras coisas, em outro lugar. A ética da filmagem se constitui com a resistência dos potenciais filmados, incluindo a interrupção como elemento constituinte da elaboração das imagens. No pensamento de Walter Benjamin, o encontro entre gerações atuais e precedentes se realiza por intermédio de uma imagem, sobressalente produção que não concerne apenas a quem se põe a lembrar sobre o que foi perdido, mas fundamentalmente, a articulação de uma posição em relação ao que sobrevém. 


\section{Subjetividade, montagem e ética no cinema documentário: pistas metodológicas entre Eduardo Coutinho e Walter Benjamim.}

Pedro Felipe Moura de ARAÚJO; Marcelo Santana FERREIRA

Relacionando a tarefa da história materialista com um trabalho sobre a reminiscência, Walter Benjamin já havia apontado que, apoderar-se da reminiscência num momento de perigo individual e coletivo se configura como um processo de reconhecimento da imagem do presente que se dirige ao próprio presente que, de outro modo, se tornaria irrecuperável. A imagética da descontinuidade da história, em Walter Benjamin, se estrutura como resistência ao fatalismo e a continuidade como normas históricas. Ao considerar o trabalho do historiador materialista voltado ao cuidado com a imagem, Benjamin sugere na Tese $\mathrm{V}$ em seu texto célebre Sobre o conceito da História: "A verdadeira imagem do passado passa por nós de forma fugidia. O passado só pode ser apreendido como imagem irrecuperável e subitamente iluminada no momento do seu reconhecimento." (2013a, p. 11). Reconhecimento se refere, fortemente, a possibilidade de citação. A citabilidade do passado se relaciona com a atitude ética que se formula no interior do campo da historiografia materialista, ou seja, a persistência no trabalho sobre as imagens do passado indica que nos sentimos visados por aquelas imagens, que concernem ao presente. A filosofia da história em Benjamin se formula como um trabalho sobre as imagens.

A reminiscência interrompe, exige um reposicionamento, dirige-se ao que foge do que havia sido prescrito. Tal tarefa filosófica e política parece encontrar um campo fértil de conexões com o exercício de Eduardo Coutinho, remetido à imprevisibilidade dos encontros viabilizados pela presença da câmera, da equipe e do corpo daqueles que, talvez, partilhem fragmentos de suas vidas com vistas a composição de um relampejo que não se assemelha ao que se produz com as máquinas de visibilidade hegemônicas em uma sociedade como a nossa.

Metodologicamente, a precariedade do encontro remexe, definitivamente, com o sentido de se estabelecer uma narrativa a partir dos dispositivos técnicos em curso na feitura de um documentário. O filme documentário se volta ao caráter ficcional daquilo mesmo que permitiu que ele fosse realizado. Para as ciências humanas, um procedimento desta magnitude fere as pretensões de universalização e de objetividade que definem a possibilidade de uma relação hegemônica com a verdade de coletivos e indivíduos estudados e representados. A imagem cinematográfica se configura como alegoria de processos históricos que são imanentes à produção de representações sobre classes sociais subalternizadas economicamente. Os subalternos não se deixam atingir pela curiosidade 


\section{Subjetividade, montagem e ética no cinema documentário: pistas metodológicas entre Eduardo Coutinho e Walter Benjamim.}

Pedro Felipe Moura de ARAÚJO; Marcelo Santana FERREIRA

mórbida da consciência culpada. Há uma necessidade de que os atores e atrizes do contexto se movimentem, se interpelem, se encontrem e se desencontrem. Não há a fria institucionalização de uma abordagem que tutelaria os encontros. Cenários indigestos também se tornam, provisoriamente, contextos de sociabilidade, fragmentos de dispersão das atividades. Homens, mulheres e crianças reiteradamente esquecidos ou silenciados fazem movimentos ousados em frente à câmera, negando a palavra final ao dispositivo e ao diretor do documentário. As vidas não são apenas o efeito mais imediato e visível do que se forja no sistema de produção capitalista, na desigual e violenta sociedade brasileira. Também indicam a contingência de suas adesões ao modelo de moralização da existência em voga no capitalismo: trabalham, como outras pessoas trabalham. Na continuidade-descontinuidade de suas existências, a interrupção da filmagem configura um gesto político que precisa ser recoberto, ou melhor, reconhecido como fragmento de uma negação da obviedade do espetáculo e da comoção despolitizada.

Em Boca de Lixo, alguns dos indivíduos filmados ficam receosos de que aquelas imagens sejam transmitidas pela televisão, exprimindo-se, muito provavelmente, a inquietação com a representação massiva da miséria. Sob a frieza e a indiferença de um modo de produção que multiplica contingentes de miseráveis, interlocutores e interlocutoras da equipe de filmagem comandada por Coutinho encontram um tempo restante para narrarem sobre seus cotidianos. Uma das mulheres filmadas pela equipe enumera, com orgulho, os filhos e filhas que já tem, ansiando para que aumente a quantidade de rebentos. Tirando do lixo seu sustento, os miseráveis lembram arqueólogos ou garimpeiros, sob as camadas de restos e de chorume, encontram boa comida, revistas, relógios, roupas, lavagem para os porcos. A imagética da produção de derrotados não se comove com os olhos hegemônicos da consciência ávida por quadros precários de humanidade. Trata-se de um exercício estético e metodológico que pode inspirar a valorização daquilo que é imanente aos encontros entre pesquisadores/pesquisadoras e os potenciais sujeitos da investigação.

Ampliando a conceitualização de imagem, pode-se considerar que uma imagética crítica dos subalternos diz respeito ao reconhecimento de vetores de subjetivação que não devem sucumbir à luminosidade compulsória dos grandes refletores. Didi-Huberman (2014) já havia refletido sobre o relampejo de fragmentos de vida que não se queimam pela superexposição em curso nas sociedades em que se forjaram grandes dispositivos de 


\section{Subjetividade, montagem e ética no cinema documentário: pistas metodológicas entre Eduardo Coutinho e Walter Benjamim.}

Pedro Felipe Moura de ARAÚJO; Marcelo Santana FERREIRA

produção de imagem dos governados. Apoiando-se em Walter Benjamin, o pensador busca caracterizar a imagem como relampejo, como o que apenas permite uma breve visada, efeito do processo de reconhecimento. A imagem do passado, por exemplo, em sua articulação de uma historiografia materialista, não se deixa fixar e não se encerra em uma objetivação do que se passou. Poder imaginar de outro modo aquilo que sobrevém é parte da tarefa ética do historiador materialista. O trabalho da imaginação não se reduz a uma vivência subjetiva, sem a transversalização de elementos estéticos e políticos que configuram uma época. $\mathrm{O}$ documentário de Coutinho faz breves paradas no cotidiano dos homens e mulheres que vivem do lixão, sobreviventes do descarte capitalista de vidas que não possuem valor. Os filhos que já foram criados com aquilo que sobrou, os filhos que ainda serão criados com aquilo que sobra já não permitem uma representação heroica ou romântica das vidas atravessadas pelas políticas de visibilidade em jogo no nosso mundo.

Uma possibilidade de metodologia se desenha aqui. $\mathrm{O}$ filme documentário não se assenta na anterioridade estabilizada da realidade. Há aspectos que concernem aos encontros que são parte inalienável do próprio filme. Acostumados a uma tradição de pensamento em que os encontros de pesquisa se dão em um vácuo ou que possuem um grau zero de significação, o cinema de Coutinho não oculta as entoações dos interlocutores, vacilando entre a certeza do que há para se perguntar e o imprevisto da resistência do eventual interlocutor. Gestos de negação da presença da câmera se coadunam com poses em frente às casas em que as pessoas moram. Diferentes camadas de imagens e palavras dão densidade aos depoimentos na montagem final. A densidade das camadas se aproxima de um trabalho arqueológico que tem grande importância para a defesa de uma metodologia de investigação renovada em ciências humanas. Há elementos que não precisam mais ser considerados como oclusivos, eles se dão a ver. Os dispositivos de investigação e de produção de imagem não evadem do cenário em que as palavras se tornam possíveis. Tal cenário interfere na proposição de produção de imagens sobre os outros. As imagens sobre os outros revelam, também, nossos limites e anseios, nossa presença e nossa opacidade. Esta ética não se esgota na multiplicação de produtos que só revelariam a integridade de nossos propósitos e a dissociação entre produção de conhecimento e interpelação entre pesquisadores e pesquisados. 


\title{
6. AOS DETRITOS, ESCREVER COM IMAGENS
}

Nestas linhas que aqui se tecem entre a escrita da história e a experiência fílmica do documentário, desejou-se produzir um deslocamento da tradição histórica dos vencedores, pela via de uma outra imagética dos derrotados apontada pelo filme do Coutinho. O trabalho das imagens em "Boca de Lixo" se aproximaria da recomendação metodológica para a atividade do historiador materialista, cunhada por Benjamin. Uma montagem de imagens que escovem "à contrapelo" a história, a partir da praxis do documentário que devolve uma parte do mundo, coincididamente, como método e obra; "um modo de fazer e uma forma de pensar", nas palavras de Comolli (2008).

Na Tese VII, em Sobre o conceito da História, Walter Benjamin retrata o "cortejo de triunfo que conduz os dominantes de hoje por cima dos que, hoje, jazem por terra" (GAGNEBIN, 2008, p. 80), buscando mostrar que a permanência dos bens culturais da história dos vencedores revelaria, em sua sombra, o trabalho não visto daqueles que ficaram soterrados pelo esquecimento, a violência subjacente da "corvéia sem nome" que compõe o seu feitio enquanto obra de cultura. Seguindo as pistas benjamininas, Jeanne-Marie Gagnebin (2008) retoma este argumento para lembrar a "todos leitores marxistas ou de esquerda de Benjamin" que o uso apressado desta Tese para "justificar sua desconfiança legítima em relação à cultura vigente, quando não seu desprezo por ela" (ibid), não dá conta da potência paradoxal da imagética dos derrotados em sua corvéia. Gagnebin afirma que estes leitores "esquecem, no mais das vezes" uma outra descrição elaborada por Benjamin sobre a luta de classes, que situa, tão enfaticamente quanto, uma imagética mais complexa deste conflito. $\mathrm{Na}$ Tese IV, lemos:

\begin{abstract}
A luta de classes, que um historiador formado em Marx tem sempre diante dos olhos, é uma luta pelas coisas duras e materiais, sem as quais não podem existir as requintadas e espirituais. E, apesar disso, estas últimas estão presentes na luta de classes de modo diverso da ideia dos despojos que cabem ao vencedor depois do saque. Elas estão vivas nessa luta sob a forma de confiança, coragem, humor, astúcia, constância, e atuam retroativamente sobre os tempos mais distantes. Elasporão permanentemente em causa todas as vitórias que algum dia coube às classes dominantes . (BENJAMIN, 2013a, p. 10-11)
\end{abstract}

Durante o filme de Coutinho são construídas, na montagem de seu espaço-tempo, formas de vida e fragmentos de experiência que interrogam nossas expectativas, envergam a 


\section{Subjetividade, montagem e ética no cinema documentário: pistas metodológicas entre Eduardo Coutinho e Walter Benjamim.}

Pedro Felipe Moura de ARAÚJO; Marcelo Santana FERREIRA

carga determinista das representações. À esta "face sombria" da origem da cultura e seus bens, frutos da luta de classes, não restaria apenas a "ideia dos despojos que cabem ao vencedor depois do saque", mas também a vivacidade tenaz e subversiva das coisas "requintadas e espirituais", coetâneas a esta mesma luta. Trata-se aqui neste "aparente paradoxo", do conceito de "atualidade" em Benjamin, que o retoma intensivamente a partir de uma outra dimensão semântica desta palavra. Atualidade em Benjamin (Aktualität), não se resumiria a ideia de presentificação, numa perspectiva elegíaca do passado - celebração de uma qualidade que permaneceu inalterável -, mas sim enquanto atualidade intensiva, "ou seja, vir a ser ato (Akt) de uma potência.” (GAGNEBIN, 2008, p. 81).

Em oposição à representação de uma linearidade contínua e ininterrupta do tempo histórico, representação cuja relevância ideológica para a manutenção do existente deve ser realçada, essa concepção disruptiva e intensiva de "atualidade" coloca em questão a narração dominante da história, isto é também, a compreensão de um passado cujo sentido pode revelar-se outro e a autocompreensão de um presente que poderia ser diferente. (ibid)

Quando de início, no filme, vemos urubus e cavalos que coabitam aquele mesmo espaço repartindo as sobras do lixo, ponderamos uma certa nivelação entre pessoas e animais, posição esta que impõe catadores e catadoras à um aplainamento mesquinho. Quatro anos antes de "Boca de Lixo" o celebrado curta-metragem "Ilhas das Flores", de Jorge Furtado (1989), ganharia repercussão internacional apostando nesta vil comparação. Utilizando-se de um raciocínio dedutivo em cadeia (MATTOS, 2003, p. 54) o filme conclui - na imagem de um depósito de lixo nos confins do Rio Grande do Sul -, que as pessoas pobres situavam-se em escala de prioridade inferior mesmo à dos porcos. Num misto de documentário e ensaio ficcional, o filme opera uma espécie de logística dramática que conduz uma vontade crítica, mas também, principalmente, a certo fatalismo desta mesma crítica, pela carga opressora e inevitável de ter que sobreviver com os restos da sociedade. Coutinho acaba por ensaiar uma "antítese" a esta proposição em "Boca do Lixo", afastando-se da continuidade da explicação única ao privilegiar um modo de filmar em que o instante também é exercício de ir de encontro ao mundo e arrancar os fragmentos e detritos de realidade; ali no lixo, ele se recusa e revira por outros usos ao que se tem por concluído. "O cinema aqui não se propõe como o

7 "Como entender esse aparente paradoxo: de um lado a cultura como testemunho da barbárie que subjaz à sua produção, do outro a cultura como manancial de tenacidade e astúcia, de humor, de resistência e de questionamento da continuidade da dominação?” (GAGNEBIN, J. 2008, p. 80) 
relato de uma investigação concluída antes do início da filmagem, mas como o instante de investigação, não tanto a descoberta quanto a procura, não tanto uma resposta quanto uma nova pergunta" (AVELLAR, 2013, p. 541). A esta aposta do filme, insurge uma experiência em que a comunicação estabelecida não visa a obediência da coleta de informações ou do endereçamento de códigos, mas um espaço de imagens críticas entre os que filmam e os que são filmados.

"Criar a história com os próprios detritos da história", incitava Walter Benjamin, ao elogiar o filósofo Goucourt, no caderno $R$ de seu Livro das Passagens (2009, p. 587). Esta que torna-se sua proposta epistemológica: não assumir a história como processo contínuo nem como um relato causal.Na tarefa do historiador materialista o passado deixa de ser um fato objetivo e transforma-se em um fato de memória, uma atualidade. Tal como o historiador benjaminiano, Eduardo Coutinho em "Boca de Lixo" aciona um deslocamento através do "presente que destrói o contínuo da história" (ibid) das representações e clichês que temos de catadores de lixo, os que vivem dos restos da lógica de consumo, e que põe questões em relação à posse e acumulação de bens. Gilles Deleuze também dizia que não vivemos numa civilização das imagens, mas numa civilização dos clichês. Nossa tarefa seria a de olhar ou criar imagens de modo que desconstruam os clichês. O lixão é apresentado como um lugar de estratégias e partilhas de sociabilidade frente a escassez. O filme encontra pessoas e constrói destas as personagens que não se encaixam como figuras obedientes às nossas representações, mas que vivem "sob a forma de confiança, coragem, humor, astúcia, constância", que como nos lembra Benjamin na quarta Tese, "porão permanentemente em causa todas as vitórias que algum dia coube às classes dominantes”. Tal como nos lembra Enock, que vive ali do lixo há anos, com sua versão astuta sobre o destino dos detritos em nossa sociedade, "o lixo é o final do serviço, mas é também dali que se inicia tudo".

\section{REFERÊNCIAS BIBLIOGRÁFICAS}

AVELlAR, J. C. O lixo na Boca. In: OHATA, Milton (Org.) Eduardo Coutinho. São Paulo - Cosac Naify, 2013, 536-42.

BENJAMIN, W. Sobre o conceito da História. In: Walter Benjamin, o anjo da história. Organização e Tradução de João Barrento. Belo Horizonte: Autêntica Editora, 2013a.

Imagens do pensamento - Sobre o haxixe e outras drogas. Edição e Tradução de João 
Barrento. Belo Horizonte: Autêntica Editora, 2013b.

Passagens. Belo Horizonte: Ed. UFMG, 2009.

BRAGANÇA, F. (org.). Eduardo Coutinho - Encontros. Rio de Janeiro: Beco do Azougue, 2008.

COMOLli, J. O espelho de duas faces. In: YOREL, G. (org.) Pensar o cinema - ética, imagem e pensamento. $1^{\text {a }}$ ed. Cosac Naify, 2015, p. 165-203.

. Ver e poder: A inocência perdida - cinema, televisão, ficção e documentário. Belo Horizonte: UFMG, 2008.

COUTINHO, E. O cinema documentário e a escuta sensível da alteridade. In: Projeto História.

Revista do Programa de Estudos Pós-graduados em História e do Departamento de História da PUC-SP, n.15 (Dossiê Ética e História Oral), p. 165-171, 1997.

DIDI-HUBERMAN, G. Sobrevivência dos vagalumes. Belo Horizonte: Editora UFMG, 2014.

GAGNEBIN, J. Documentos de cultura / documentos de barbárie. Ide - psicanálise e cultura, São Paulo, v. I, n.1, p. 80-82, 2008.

GUIMARÃES, C. A experiência histórica e o irreparável. 2014. (Palestra apresentada no cineclube da UFRJ Ciência em Foco).

Comum, ordinário e popular: figuras de alteridade no documentário brasileiro contemporâneo. In: MIGLIORIN, C. (Org.) Ensaios no real - O documentário brasileiro hoje. Rio de Janeiro - Azougue, 2010, p. 181-197.

A singularidade como figura lógica e estética no documentário. Alceu (PUCRJ), Rio de Janeiro, v. 7, n.13, p. 38-48, 2006.

IVENS, J. Documentário: subjetividade e montagem in: LABAKI, A (org.) A verdade de cada um. $1^{\text {a }}$ ed. Cosac Naify, 2015, p. 41-51.

LINS, C. da L. O documentário de Eduardo Coutinho: televisão, cinema e vídeo. 3. ed. Rio de Janeiro: Jorge Zahar Editor, 2004.

MATTOS, C. A. Eduardo Coutinho: o homem que caiu na real. Santa Maria da Feira, Portugal: Festival de Cinema Luso-Brasileiro de Santa Maria da Feira, 2003. 120 p.

MIGLIORIN, C. Ensaio na revolução: o documentarista e o acontecimento. In: Osmar Gonçalves. (Org.). Narrativas sensoriais. 1ed. Rio de Janeiro: Funarte, v. 1, p. 235-261, 2014.

REZENDE, L. A. Microfísica do Documentário - Ensaio sobre criação e ontologia do documentário. 1. ed. Rio de Janeiro: Azougue/ FAPERJ, 2013.

RODRIGUEZ, Maria del Carmen. Imagens do tempo no cinema (versão deleuziana). In: YOREL, G. (org.) Pensar o cinema - ética, imagem e pensamento. $1^{\text {a }}$ ed. Cosac Naify, 2015, p. 91-123. 
TEIXEIRA, F. E. Documentário moderno. In: História do cinema mundial (org.) Fernando Mascarello. Papirus, 2ed. São Paulo, 2007, p. 253-87.

WISEMAN, F. A montagem como uma conversa a quatro vozes. in: LABAKI, A (org.) A verdade de cada um. Cosac Naify, 2015, p. 184-91

\section{CINEMATOGRÁFICAS}

BOCA de Lixo. Dir: Eduardo Coutinho. Produção: Centro de Cultura e Imagem Popular (CECIP). Rio de Janeiro, 1993, (média-metragem, 50min)

ILHA das Flores. Direção: Jorge Furtado. Rio Grande do Sul, 1989 (curta-metragem, 13min) 